\title{
Borderline Ovarian Endometrioid Adenofibroma
}

National Cancer Institute

\section{Source}

National Cancer Institute. Borderline Ovarian Endometrioid Adenofibroma. NCI

Thesaurus. Code C40069.

An epithelial neoplasm that arises from the ovary characterized by the presence of glandular or cystic spaces which contain atypical glandular epithelial cells resembling endometrial cells. The surrounding ovarian stroma is fibrotic. There is no evidence of stromal invasion. 